\title{
Survival in patients with oral and maxillofacial diffuse large B-cell lymphoma
}

\begin{abstract}
Janet Ofelia Guevara-Canales(a) Rafael Morales-Vadillo(b)

Carlos Enrique Cava-Vergiú(c)

Fabiola Pessoa Pereira Leite ${ }^{(d)}$

Henrique Duque de Miranda

Chaves Netto(e)

Fernando Augusto Soares ${ }^{(f)}$

Maria das Graças Afonso Miranda Chaves(g)
\end{abstract}

(a) Departamento de Medicina y Patología Oral y Maxilofacial, Facultad de

Odontología, Univ de San Martín de Porres - USMP, Lima, Peru.

(b) Departamento de Investigación Clínica, Facultad de Odontología, Univ de San

Martín de Porres - USMP, Lima, Peru.

(c) Departamento de Cirugía Oral y Maxilofacial, Facultad de Odontología, Univ de San Martín de Porres - USMP, Lima, Peru.

(d) Departamento de Reabilitação, Faculdade de Odontologia, Univ Federal de Juiz de

Fora - UFJF, Juiz de Fora, MG, Brazil.

(e) Departamento de Cirurgia Oral e Maxilofacial, Faculdade de Odontologia, Univ Federal de Juiz de Fora - UFJF, Juiz de Fora, MG, Brazil.

(f) Departamento de Anatomia Patológica, Hospital AC Camargo, São Paulo, SP, Brazil.

(g) Departamento de Pós-graduação, Faculdade de Odontologia, Univ Federal de Juiz de Fora - UFJF, Juiz de Fora, MG, Brazil.

Declaration of Interests: The authors certify that they have no commercial or associative interest that represents a conflict of interest in connection with the manuscript.

Corresponding Author: Janet Ofelia Guevara-Canales E-mail: janetguevara7@hotmail.com

Submitted: Nov 22, 2012

Accepted for publication: Mar 29, 2013

Last revision: Apr 15, 2013
Abstract: The purpose of this study was to determine the survival and prognostic factors of patients with diffuse large B-cell lymphoma (DLBCL) of the oral cavity and maxillofacial region. Retrospectively, the clinical records of patients with a primary diagnosis of DLBCL of the oral cavity and maxillofacial region treated at the A.C. Camargo Hospital for Cancer, São Paulo, Brazil, between January 1980 and December 2005 were evaluated to determine (A) overall survival (OS) at 2 and 5 years and the individual survival percentage for each possible prognostic factor by means of the actuarial technique (also known as mortality tables), and the Kaplan Meier product limit method (which provided the survival value curves for each possible prognostic factor); (B) prognostic factors subject to univariate evaluation with the log-rank test (also known as Mantel-Cox), and multivariate analysis with Cox's regression model (all the variables together). The data were considered significant at $\mathrm{p} \leq 0.05$. From 1980 to 2005, 3513 new cases of lymphomas were treated, of which 151 (4.3\%) occurred in the oral cavity and maxillofacial region. Of these 151 lesions, 48 were diffuse large B-cell lymphoma, with $64 \%$ for OS at 2 years and $45 \%$ for OS at 5 years. Of the variables studied as possible prognostic factors, multivariate analysis found the following variables have statistically significant values: age $(p=0.042)$, clinical stage $(\mathrm{p}=0.007)$ and performance status $(\mathrm{p}=0.031)$. These data suggest that patients have a higher risk of mortality if they are older, at a later clinical stage, and have a higher performance status.

Descriptors: Lymphoma, Large B-Cell, Diffuse; Survival; Mouth Neoplasms; Prognosis.

\section{Introduction}

Lymphomas represent a heterogeneous group of malignant clonal diseases. The characteristic they share is that they arise as a result of somatic mutation of a lymphocyte progenitor. ${ }^{1}$ Although lymphomas represent less than $5 \%$ of all oral cancers, ${ }^{2}$ they are the most frequent nonepithelial malignant tumors in the oral cavity and maxillofacial region (OC-MR). ${ }^{3}$ Further, lymphoma is a general term for a complex group of malignant neoplasms of the lymphoreticular system, ${ }^{4}$ traditionally defined as either Hodgkin lymphoma (HL) or non-Hodgkin lymphoma (NHL). ${ }^{5}$ The current classification of lymphoma subtypes was proposed by the World Health Organization in $2008 .^{6}$ 
NHL occurs mainly in the lymph nodes, though approximately $24 \%$ of cases affect extra-nodal locations, ${ }^{7,8}$ such as stomach, skin, lung, central nervous system, orbit, salivary glands and oral cavity. ${ }^{9}$ The type of NHL most frequently diagnosed is DLBCL, which is in turn the most frequent type of primary lymphoma of the oral cavity. ${ }^{10,11}$ Factors which have been shown to have significant influence on the survival of patients with NHL include:

- age,

- presence or absence of constitutional symptoms,

- performance status,

- serum lactate dehydrogenase (LDH),

- Ann Arbor stage,

- tumor size,

- number of nodal and extranodal disease sites, and

- bone marrow involvement. ${ }^{12,13}$

It is important to identify, measure, and interpret the characteristics of alterations which have prognostic implications and influence in a DLBCL patient's survival. This is important to predict patient survival, and to understand the natural history of the disease in order to provide an appropriate treatment plan according to the response to therapy. Thus, the purpose of the study was to determine the survival and prognostic factors of patients with DLBCL of the oral cavity and maxillofacial region.

\section{Methodology}

An observational, descriptive, cross-sectional, retrospective research design was followed. The patients included in this study were treated at A.C. Camargo Hospital for Cancer, São Paulo, Brazil, between January 1980 and December 2005 and their clinical histories contained a primary diagnosis of DLBCL of the OC-MR. Clinical records with incomplete data were excluded.

Overall survival was defined as the percentage of patients remaining alive during the period from the beginning of treatment to the last visit or date of death (in years). The following variables were considered for the analysis of prognostic factors:

- age,

- gender,

- location,
- size of lesion,

- increased volume,

- pain,

- local symptoms,

- general symptoms,

- histologic malignancy grade (according to The International Working Formulation for Clinical Usage), ${ }^{14}$

- clinical stage (based on the Ann Arbor staging system), ${ }^{15-17}$

- International Prognostic Index (IPI), ${ }^{18}$

- performance status evaluated according to the Eastern Cooperative Oncology Group (ECOG), ${ }^{19}$

- serum concentration of LDH,

- extranodal involvement,

- treatment,

- follow-up state and

- follow-up time.

The collected data were transferred to the Microsoft Excel program (Microsoft, Inc., Redmond, USA), and the analysis was conducted with the Statistical Package for Social Sciences - SPSS (version 18.0 for Windows, IBM Inc., Chicago, USA).

Survival analysis was calculated using two statistical tests:

1. the actuarial technique (also known as mortality tables) to determine the percentage of OS at 2 and 5 years and the percentage of individual survival for each possible prognostic factor and

2. the Kaplan Meier product limit method, a test that provides the curves or lines for the survival value for each possible prognostic factor.

Prognostic factors were evaluated in two ways:

1. univariate analysis, with the log-rank test (also known as Mantel-Cox) which provides the statistical significance of the differences between the survival curves or lines of the Kaplan Meier product limit individually for each variable and

2. multivariate analysis, using the Cox regression model, considering all variables and possible prognostic factors together.

For all cases, significance was considered as $\mathrm{p} \leq 0.05$. 


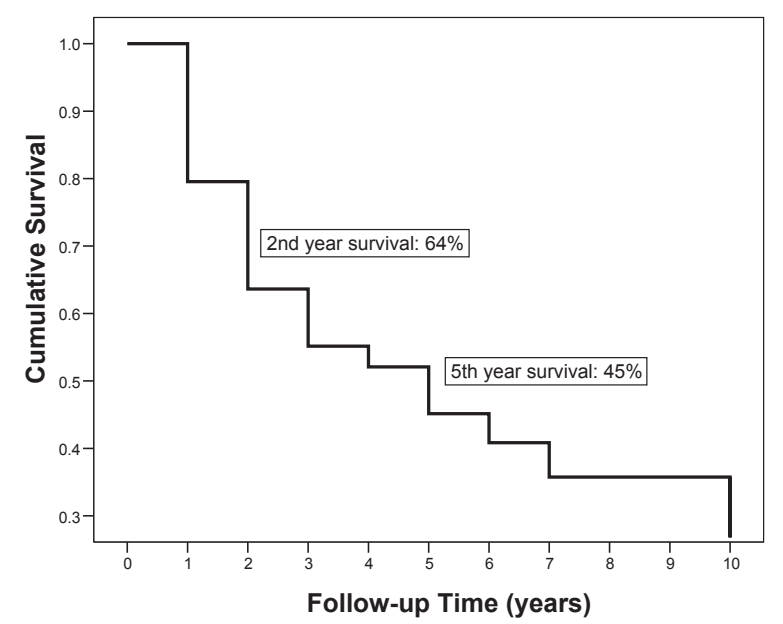

Figure 1 - Overall survival curve for patients with DLBCL of the OC-MR, seen at the A.C. Camargo Hospital for Cancer, between January 1980 and December 2005.

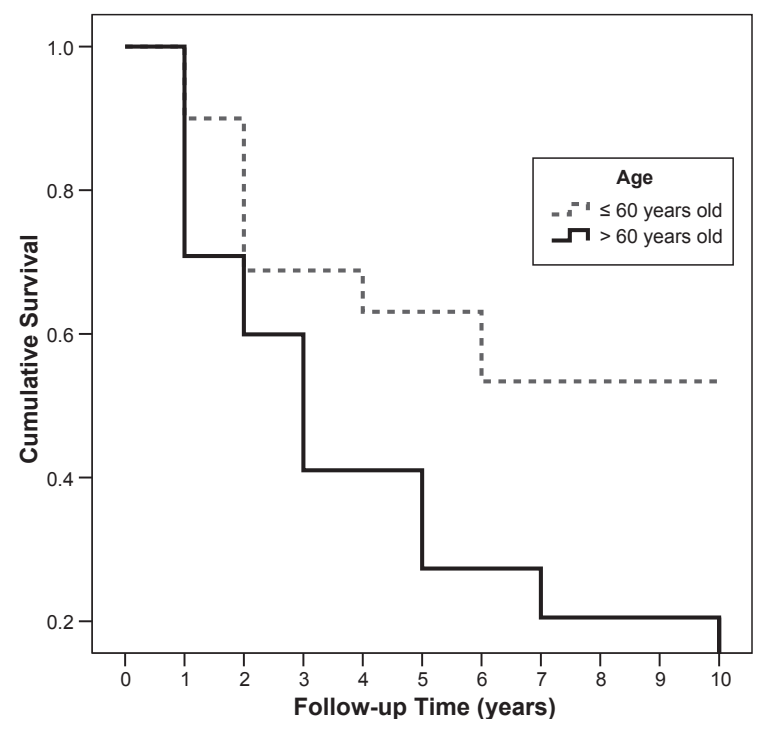

Figure 2 - Mortality and Kaplan-Meier curves with univariate significance determined by the log-rank test, age predictor, for subjects with DLBCL of the OC-MR, seen at the A.C. Camargo Hospital for Cancer, between January 1980 and December 2005.

\section{Results}

From January 1980 to December 2005, 3513 new cases of lymphoma were treated at the A.C. Camargo Hospital, of which 151 (4.3\%) occurred in the OC-MR. Of these 151 lymphomas, 48 (31.79\%) were DLBCL. Of the 48 patients evaluated, OS was

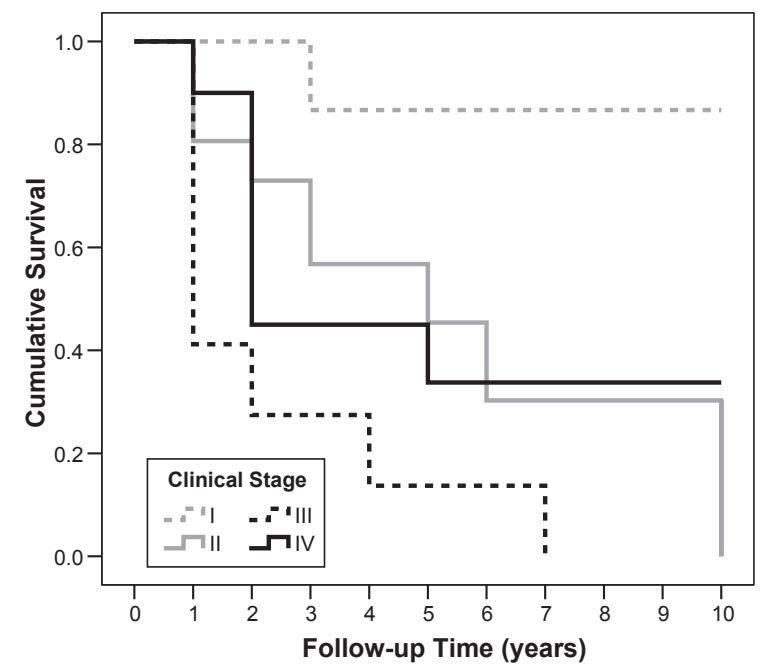

Figure 3 - Mortality and Kaplan-Meier curves with univariate significance determined by the log-rank test, clinical stage predictor, for subjects with DLBCL of the OC-MR, seen at the A.C. Camargo Hospital for Cancer, between January 1980 and December 2005.

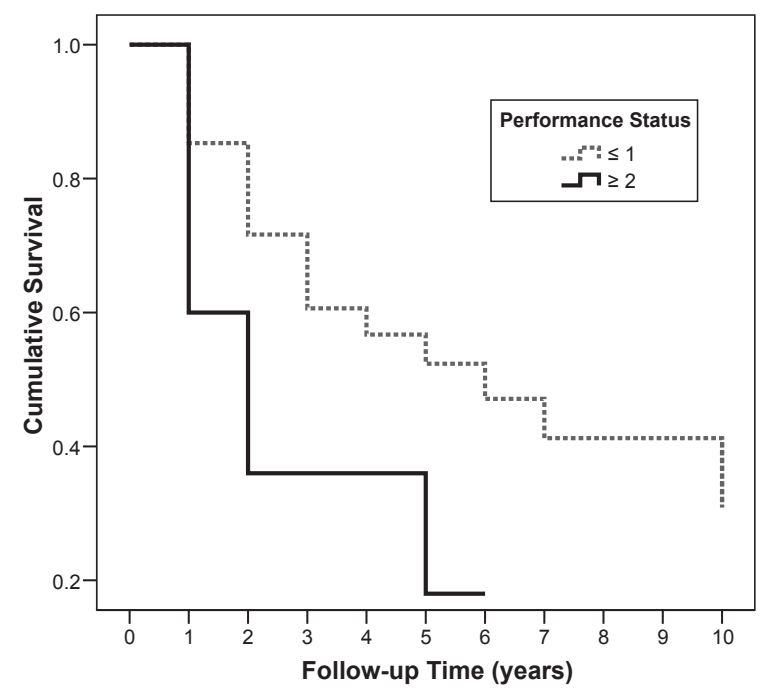

Figure 4 - Mortality and Kaplan-Meier curves with univariate significance determined by the log-rank test, performance status predictor, for subjects with DLBCL of the OC-MR, seen at the A.C. Camargo Hospital for Cancer, between January 1980 and December 2005.

$64 \%$ at 2 years and $45 \%$ at 5 years (Figure 1).

Table 1 shows the survival percentage and significance value for each variable analyzed as a possible prognostic factor for survival.

Multivariate analysis of different variables studied as possible prognostic factors showed three sta- 
Table 1 - Percent survival at 2 and 5 years evaluated for possible prognostic factors for subjects with DLBCL of the OC-MR. (continued on next page)

\begin{tabular}{|c|c|c|c|c|c|}
\hline Risk factors & & $\begin{array}{l}\text { Survival } \\
\text { at } \\
2 \text { years } \\
(\%)\end{array}$ & $\begin{array}{l}\text { Survival } \\
\text { at } \\
5 \text { years } \\
(\%)\end{array}$ & $\begin{array}{c}\mathrm{p} \text { value } \\
\text { according to log } \\
\text { rank (univariate) }\end{array}$ & $\begin{array}{c}p \text { value } \\
\text { according to Cox } \\
\text { (multivariate) }\end{array}$ \\
\hline \multirow{2}{*}{ Age } & $\leq 60$ & 69 & 63 & $0.036^{*}$ & $0.042^{*}$ \\
\hline & $>60$ & 60 & 27 & & \\
\hline \multirow{2}{*}{ Gender } & Female & 70 & 48 & 0.691 & 0.131 \\
\hline & Male & 58 & 43 & & \\
\hline \multirow{5}{*}{ Location } & Oral cavity & 78 & 28 & 0.997 & 0.683 \\
\hline & Palatine tonsil & 60 & 48 & & \\
\hline & Maxillary bones & 50 & 50 & & \\
\hline & Maxillary sinus & 67 & 33 & & \\
\hline & Major salivary glands & 61 & 61 & & \\
\hline \multirow{2}{*}{ Size of lesion } & $\leq 4 \mathrm{~cm}$ & 65 & 44 & 0.992 & 0.208 \\
\hline & $>4 \mathrm{~cm}$ & 56 & 44 & & \\
\hline \multirow{2}{*}{$\begin{array}{l}\text { Increased } \\
\text { volume }\end{array}$} & No & 68 & 56 & 0.279 & 0.481 \\
\hline & Yes & 61 & 39 & & \\
\hline \multirow{2}{*}{ Pain } & No & 64 & 53 & 0.261 & 0.734 \\
\hline & Yes & 62 & 35 & & \\
\hline \multirow{2}{*}{$\begin{array}{l}\text { Local } \\
\text { symptoms }\end{array}$} & No & 64 & 45 & - & - \\
\hline & Yes & - & - & & \\
\hline \multirow{2}{*}{$\begin{array}{l}\text { General } \\
\text { symptoms }\end{array}$} & No & 68 & 47 & 0.382 & 0.079 \\
\hline & Yes & 52 & 37 & & \\
\hline \multirow{4}{*}{$\begin{array}{l}\text { Histologic } \\
\text { grade }\end{array}$} & Undetermined & 62 & 47 & 0.435 & 0.802 \\
\hline & Low & 100 & 50 & & \\
\hline & Intermediate & 61 & 41 & & \\
\hline & High & 45 & 45 & & \\
\hline \multirow{4}{*}{$\begin{array}{l}\text { Clinical } \\
\text { stage }\end{array}$} & Stage I & 100 & 87 & $0.000^{*}$ & $0.007^{*}$ \\
\hline & Stage II & 73 & 45 & & \\
\hline & Stage III & 27 & 14 & & \\
\hline & Stage IV & 45 & 34 & & \\
\hline \multirow{6}{*}{ IPI } & 0 & 100 & 100 & $0.005^{*}$ & 0.436 \\
\hline & 1 & 100 & 100 & & \\
\hline & 2 & 100 & 87 & & \\
\hline & 3 & 57 & 26 & & \\
\hline & 4 & 26 & 26 & & \\
\hline & 5 & 43 & 0 & & \\
\hline \multirow{2}{*}{$\begin{array}{l}\text { Performance } \\
\text { status }\end{array}$} & $\leq 1$ & 72 & 52 & $0.028^{*}$ & $0.031^{*}$ \\
\hline & $\geq 2$ & 36 & 18 & & \\
\hline \multirow{2}{*}{ LDH } & $\leq 200 \mathrm{U} / \mathrm{L}$ & 100 & 100 & 0.108 & 0.516 \\
\hline & $>200 \mathrm{U} / \mathrm{L}$ & 61 & 42 & & \\
\hline \multirow{2}{*}{$\begin{array}{l}\text { Extranodal } \\
\text { involvement }\end{array}$} & $\leq 1$ & 100 & 87 & $0.005^{*}$ & - \\
\hline & $>1$ & 53 & 34 & & \\
\hline
\end{tabular}


Table 1 - (continued)

\begin{tabular}{|c|c|c|c|c|c|}
\hline Risk factors & & $\begin{array}{l}\text { Survival } \\
\text { at } \\
2 \text { years } \\
\text { (\%) }\end{array}$ & $\begin{array}{l}\text { Survival } \\
\text { at } \\
5 \text { years } \\
\text { (\%) }\end{array}$ & $\begin{array}{l}\text { p value } \\
\text { according to log } \\
\text { rank (Univariate) }\end{array}$ & $\begin{array}{c}\text { p value } \\
\text { according to Cox } \\
\text { (Multivariate) }\end{array}$ \\
\hline \multirow{8}{*}{ Treatment } & Cht & 61 & 43 & 0.694 & 0.310 \\
\hline & $\mathrm{Cht}+\mathrm{Rt}$ & 69 & 45 & & \\
\hline & Rt & 39 & 39 & & \\
\hline & $\mathrm{Cht}+\mathrm{Rt}+\mathrm{Sg}$ & 100 & - & & \\
\hline & $\mathrm{Cht}+\mathrm{Sg}$ & - & - & & \\
\hline & $\mathrm{Sg}+\mathrm{Rt}$ & - & - & & \\
\hline & $\mathrm{Sg}$ & - & - & & \\
\hline & No treatment & - & - & & \\
\hline
\end{tabular}

* Statistically significant value. IPI: International Prognostic Index, LDH: lactate dehydrogenase, Cht: chemotherapy, Rt: radiotherapy, Sg: surgery.

tistically significant factors:

- age $(\mathrm{p}=0.042)$ (Figure 2),

- clinical stage ( $\mathrm{p}=0.007)$ (Figure 3$)$ and

- performance status $(\mathrm{p}=0.031)$ (Figure 4).

The mortality risk was found to be 0.603 times higher in patients over 60 years of age than in patients aged 60 years or less. Survival was found to be 0.789 times better in patients at clinical stage I than in those at clinical stage IV. Similarly, the mortality risk was 0.716 times less in patients with a performance status of 1 or lower compared to patients with performance status of 2 or higher (Table 2).

\section{Discussion}

In this study, the 48 DLBCLs evaluated corresponded to $31.79 \%$ of the NHL patients treated at Hospital A.C. Camargo for Cancer between 1980 and 2005, which is slightly lower than the DLBCL values reported in the case series studies performed by van der Wall et al., ${ }^{1}$ Kemp et al. ${ }^{5}$ and Solomides et al. ${ }^{10}$ in which they accounted for $50 \%, 58 \%$ and $68 \%$, respectively of all oral NHL. Although DLBCL represents about $30 \%$ to $40 \%$ of NHL cases in general, its predominance is even higher in the oral cavity and this is probably explained by its propensity to occur at a single extranodal site. ${ }^{5}$

Factors that have been found to influence survival significantly in patients with DLBCL include:

- the presence or absence of constitutional symptoms,
Table 2 - Potential risk factors associated with survival for subjects with DLBCL of the OC-MR, according to multivariate hazard ratio of Cox analysis.

\begin{tabular}{c|c|c|c}
\hline $\begin{array}{l}\text { Variable } \\
\text { analyzed }\end{array}$ & $\begin{array}{c}\text { Hazard } \\
\text { ratio }\end{array}$ & $\begin{array}{c}\text { Confidence } \\
\text { interval 95\% }\end{array}$ & $\begin{array}{c}\text { p value according } \\
\text { to Cox } \\
\text { (multivariate) }\end{array}$ \\
\hline Age & $0.042^{*}$ \\
\hline$\leq 60$ & 0.397 & $0.162-0.973$ & \\
\hline$>60$ & 1.0 & & $0.007^{*}$ \\
\hline Clinical stage \\
\hline Stage I & 0.211 & $0.220-2.028$ & \\
\hline Stage II & 1.392 & $0.421-4.602$ & \\
\hline Stage III & 4.387 & $1.209-15.921$ & \\
\hline Stage IV & 1.0 & & $0.031^{*}$ \\
\hline Performance status & & \\
\hline$\leq 1$ & 0.284 & $0.900-0.894$ & \\
\hline & 1.0 & &
\end{tabular}

* Statistically significant value.

- LDH,

- Ann Arbor stage, and

- involvement of bone marrow. ${ }^{12,20,21}$

Studies such as that of Møller et al. ${ }^{22}$ reported the survival of patients with DLBCL without specifying the location of the tumor, and found an overall survival rate of $85 \%$ at 5 years, which is much higher than the value determined in this study $(45 \%$ at 5 years). This may be because in cases in OC- 
MR, patients often take too long to seek medical attention, which results in more difficult treatment and poorer prognosis. Vose $^{23}$ reported a survival rate of about $50 \%$ at 5 years, which is similar to the result found in our study.

Multivariate analysis of prognostic factors showed that factors having significant influence are age, clinical stage and performance status. This corresponds with the results reported by Møller et al., ${ }^{22}$ who also found that age and clinical stage influence the survival of patients with DLBCL. Ho et al. ${ }^{24}$ also report that the prognosis is influenced by clinical stage and histologic grade because large cell lymphomas are considered aggressive and have a poor prognosis.

Many variables have been studied with regards to the survival prognosis of patients with DLBCL, such as hematological and biochemical profiles. Even though these profiles are often normal, patients may have a reduction in the number of peripheral blood lymphocytes, reductions in serum albumin levels, and increases in LDH, which has been shown to cor-

\section{References}

1. van der Waal RI, Huijgens PC, van der Valk P, van der Waal I. Characteristics of 40 primary extranodal non-Hodgkin lymphomas of the oral cavity in perspective of the new WHO classification and the International Prognostic Index. Int J Oral Maxillofac Surg. 2005 Jun;34(4):391-5.

2. Eisenbud L, Sciubba J, Mir R, Sachs SA. Oral presentations in non-Hodgkin's lymphoma: a review of thirty-one cases. Part I. Data analysis. Oral Surg Oral Med Oral Pathol. 1983 Aug;56(2):151-6.

3. Shindoh M, Takami T, Arisue M, Yamashita T, Saito T, Kohgo T, et al. Comparison between submucosal (extra-nodal) and nodal non-Hodgkin's lymphoma (NHL) in the oral and maxillofacial region. J Oral Pathol Med. 1997 Jul;26(6):283-9.

4. Epstein JB, Epstein JD, Le ND, Gorsky M. Characteristics of oral and paraoral malignant lymphoma: a population-based review of 361 cases. Oral Surg Oral Med Oral Pathol Oral Radiol Endod. 2001 Nov;92(5):519-25.

5. Kemp S, Gallagher G, Kabani S, Noonan V, O’Hara C. Oral non-Hodgkin's lymphoma: review of the literature and World Health Organization classification with reference to 40 cases. Oral Surg Oral Med Oral Pathol Oral Radiol Endod. 2008 Feb;105(2):194-201. relate with a poor prognosis. ${ }^{25}$ Some authors have not found the expression of $\mathrm{Bcl}-2$ protein, though it occurs in $30 \%$ to $60 \%$ of cases, and it has been found to have prognostic value. ${ }^{26}$ Nevertheless, other studies suggest that the expression of Bcl-2 is related to a significantly poorer survival rate. ${ }^{27}$ It has also been reported that multiple myeloma oncogene 1 (MUM1) expression is significantly associated to a lower survival rate. ${ }^{28}$ The study by Bhattacharyya et al. ${ }^{29}$ considered the type of DLBCL in the oral cavity as a prognostic factor. Similarly, Tibiletti et al. ${ }^{30}$ evaluated fluorescence in situ hybridization to detect the heterogeneity of DLBCL and identify alterations with prognostic implications.

\section{Conclusion}

According to the results of this study, it may be concluded that the mortality risk is significantly higher in patients with OC-MR DLBCL who are older, at a higher clinical stage, and have higher performance status suggesting these are survival prognosis factors.

6. Jaffe ES. The 2008 WHO classification of lymphomas: implications for clinical practice and translational research. Hematology Am Soc Hematol Educ Program. 2009;2009(1):523-31.

7. Clark RM, Fitzpatrick PJ, Gospodarowicz MK. Extranodal malignant lymphomas of the head and neck. J Otolaryngol. 1983 Aug;12(4):239-45.

8. Spatafore CM, Keyes G, Skidmore AE. Lymphoma: an unusual oral presentation. J Endod. 1989 Sep;15(9):438-41.

9. Otter R, Gerrits WB, vd Sandt MM, Hermans J, Willemze R. Primary extranodal and nodal non-Hodgkin's lymphoma. A survey of a population-based registry. Eur J Cancer Clin Oncol. 1989 Aug;25(8):1203-10.

10. Solomides CC, Miller AS, Christman RA, Talwar J, Simpkins H. Lymphomas of the oral cavity: histology, immunologic type, and incidence of Epstein-Barr virus infection. Hum Pathol. 2002 Feb;33(2):153-7.

11. Kolokotronis A, Konstantinou N, Christakis I, Papadimitriou P, Matiakis A, Zaraboukas T, et al. Localized B-cell nonHodgkin's lymphoma of oral cavity and maxillofacial region: a clinical study. Oral Surg Oral Med Oral Pathol Oral Radiol Endod. 2005 Mar;99(3):303-10. 
12. Coiffier B, Gisselbrecht C, Vose JM, Tilly H, Herbrecht R, Bosly A, et al. Prognostic factors in aggressive malignant lymphomas: description and validation of a prognostic index that could identify patients requiring a more intensive therapy. The Groupe d'Etudes des Lymphomes Agressifs. J Clin Oncol. 1991 Feb;9(2):211-9.

13. Velasquez WS, Fuller LM, Jagannath S, Tucker SL, North LB, Hagemeister FB, et al. Stages I and II diffuse large cell lymphomas: prognostic factors and long-term results with CHOP-bleo and radiotherapy. Blood. 1991 Mar 1;77(5):942-7.

14. National Cancer Institute sponsored study of classifications of non-Hodgkin's lymphomas: summary and description of a working formulation for clinical usage. The Non-Hodgkin's Lymphoma Pathologic Classification Project. Cancer. 1982 May 15;49(10):2112-35.

15. Carbone PP, Kaplan HS, Musshoff K, Smithers DW, Tubiana M. Report of the Committee on Hodgkin's disease staging classification. Cancer Res. 1971 Nov;31(11):1860-1.

16. Rosenberg SA. Validity of the Ann Arbor staging classification for the non-Hodgkin's lymphomas. Cancer Treat Rep. 1977 Sep;61(6):1023-7.

17 Moormeier JA, Williams SF, Golomb HM. The staging of nonHodgkin's lymphomas. Semin Oncol. 1990 Feb;17(1):43-50.

18. A predictive model for aggressive non-Hodgkin's lymphoma. The International Non-Hodgkin's Lymphoma Prognostic Factors Project. N Engl J Med. 1993 Sep 30;329(14):987-94.

19. Mounier N, Morel P, Haioun C, Coiffier B, Tilly H, Chatelain $\mathrm{C}$, et al. A multivariate analysis of the survival of patients with aggressive lymphoma: variations in the predictive value of prognostic factors during the course of the disease. Groupe d'Etudes des lymphomes de l'Adulte. Cancer. 1998 May 15;82(10):1952-62.

20. Shipp MA, Harrington DP, Klatt MM, Jochelson MS, Pinkus GS, Marshall JL, et al. Identification of major prognostic subgroups of patients with large-cell lymphoma treated with m-BACOD or M-BACOD. Ann Intern Med. 1986 Jun;104(6):757-65.

21. Litam P, Swan F, Cabanillas F, Tucker SL, McLaughlin P, Hagemeister FB, et al. Prognostic value of serum beta-2 mi- croglobulin in low-grade lymphoma. Ann Intern Med. 1991 May 15;114(10):855-60.

22. Møller MB, Pedersen NT, Christensen BE. Factors predicting long-term survival in low-risk diffuse large B-cell lymphoma. Am J Hematol. 2003 Oct;74(2):94-8.

23. Vose JM. Current approaches to the management of nonHodgkin's lymphoma. Semin Oncol. 1998 Aug;25(4):483-91.

24. Ho FC, Todd D, Loke SL, Ng RP, Khoo RK. Clinico-pathological features of malignant lymphomas in 294 Hong Kong Chinese patients, retrospective study covering an eight-year period. Int J Cancer. 1984 Aug 15;34(2):143-8.

25. de Leval L, Braaten KM, Ancukiewicz M, Kiggundu E, Delaney T, Mankin HJ, et al. Diffuse large B-cell lymphoma of bone: an analysis of differentiation-associated antigens with clinical correlation. Am J Surg Pathol. 2003 Sep;27(9):126977.

26. Pezzella F, Tse AG, Cordell JL, Pulford KA, Gatter KC, Mason DY. Expression of the bcl-2 oncogene protein is not specific for the 14;18 chromosomal translocation. Am J Pathol. 1990 Aug;137(2):225-32.

27. Rantanen S, Imonni O, Joensuu H, Franssila K, Knuutila $\mathrm{S}$. Causes and consequences of BCL2 overexpression in diffuse large B-cell lymphoma. Leuk Lymphoma. 2001 SepOct;42(5):1089-98.

28. Hans CP, Weisenburger DD, Greiner TC, Gascoyne RD, Delabie J, Ott G, et al. Confirmation of the molecular classification of diffuse large B-cell lymphoma by immunohistochemistry using a tissue microarray. Blood. 2004 Jan 1;103(1):275-82.

29. Bhattacharyya I, Chehal HK, Cohen DM, Al-Quran SZ. Primary diffuse large B-cell lymphoma of the oral cavity: germinal center classification. Head Neck Pathol. 2010 Sep;4(3):181-91.

30. Tibiletti MG, Martin V, Bernasconi B, Del Curto B, Pecciarini L, Uccella S, et al. BCL2, BCL6, MYC, MALT 1, and BCL10 rearrangements in nodal diffuse large B-cell lymphomas: a multicenter evaluation of a new set of fluorescent in situ hybridization probes and correlation with clinical outcome. Hum Pathol. 2009 May;40(5):645-52. 